УДК 631.48:631.618, DOI 10.31210/visnyk2018.04.19

(C) 2018

Кацевич В. В., викладач,

Грицан Ю. І., доктор біологічних наук

Дніпровський державний аграрно-економічний університет

\title{
ЕДАФІЧНА ХАРАКТЕРИСТИКА ДЕРНОВО-ЛІТОГЕННИХ ГРУНТІВ НА СІРО-ЗЕЛЕНИХ ГЛИНАХ НА ЗАСАДАХ ЕКОЛОГІЧНОЇ МІКРОМОРФОЛОГІЇ
}

\section{Рецензент - доктор сільськогосподарських наук, професор П. В. Писаренко}

Наведено агроекологічне обтрунтування прочесу грунтоутворення та результати мікроморфологічного дослідження дерново-літогенних трунтів на сіро-зелених глинах науково-дослідного стаціонару ДДАЕУ з сільськогосподарської рекультивації земель. Виявлено особливості мікроморфологічної будови техноземів пробної ділянки сільськогосподарської рекультивації. Встановлено найбільи характерні новоутворення досліджуваного профілю, а саме дрібнозернистий кальцит, який насичує матеріал основи, та його вицвіти в порах.

Ключові слова: едафотоп, дерново-літогенні трунти на сіро-зелених глинах, мікроморфологія трунтів, трунтогенез, структуроутворення.

Постановка проблеми. Під час видобутку корисних копалин 3 обігу, на жаль, неминуче вилучаються нові сільськогосподарські і лісові угіддя, і відповідно зростають площі порушених земель. В Україні під розробку корисних копалин відведено до 150 тис. га, хвостосховищами зайнято 40 тис. га, полями фільтрації і ставками (відстійниками) - 30 тис. га. Тільки в Дніпропетровській та Запорізькій областях загальна площа розвіданого родовища Нікопольського марганцеворудного басейну складає 46,7 тис. га земель, 3 яких $98 \%$ є родючими, придатними для обробітку сільськогосподарських культур.

У цілому в Україні швидкість відчуження земель під гірські роботи значно випереджає темпи повернення рекультивованих площ. У результаті проблема рекультивації та повернення в народногосподарське використання порушених земель стає першочерговою державною проблемою.

Аналіз останніх досліджень i публікацій, у яких започатковано розв'язання проблеми. Незважаючи на наявність ряду публікацій з питань техноземів, сформованих під час сільськогосподарської рекультивації (Масюк, 1975; Етеревская, 1977; Бекаревич, 1984; Кобец А. С., Волох П. В., Узбек И. Х., Демидов А.А. Грицан Ю.І., Жуков А.В. та ін., 2012), їх властивості, режими та екологічні функції залишаються не- достатньо вивченими, особливо якщо врахувати, що всі ці параметри мають чітко виражену регіональну й індивідуальну специфіку. Зокрема вивчення мінливості екологічних та едафічних властивостей, продуктивності та родючості грунтів, які відновлюються, є найважливішим методичним прийомом для оцінки ефективності процесу рекультивації [3].

Тому для отримання уявлення про сучасний стан дерново-літогенних грунтів на сіро-зелених глинах науково-дослідного стаціонару ДДАЕУ 3 сільськогосподарської рекультивації земель, як оціночний метод дослідження ми застосовували мікроморфологічний метод аналізу мікрокомпонентів грунтів: мінеральних та органічних за Беловою Н. А., Балалаєвим А. К. [5].

Слід відмітити, що для проведення грунтових досліджень у більшості випадків необхідно зруйнувати цілісність відібраного зразка грунту. Однак мікроморфологічний метод аналізу забезпечує дослідження структурних взаємозв'язків компонентів грунту у непорушеному стані і дає можливість проникнути в глибинні процеси грунтогенезу та дослідити такі процеси, як гумусонакопичення, структуроутворення, формування мінеральних новоутворень.

В. Кубієна (1967) виділяв такі основні одиниці мікроустрою - скелет та плазма.

До скелету Кубієна відносить зерна мінералів, уламки порід, міцні часточки грубого гумусу та залишки організмів.

Плазма - найбільш тонкі, активні, новоутворені речовини грунту, які рухаються та змінюють свій склад, форму та здатні перевідкладатися.

За характером сполучення цих основних одиниць Кубієна виділяв типи елементарного мікроустрою [9].

Аналізуючи будову грунту, використовують запропоновані Р. Брюером (1964) наступні одиниці організації: основа (S-matrix), педи (peds), грунтові утворення (pedological features) та шпарини (pores). 


\section{СІЛЬСЬКЕ ГОСПОДАРСТВО. ЕКОЛОГІЯ}

Розглянуті компоненти мікроустрою грунту не однакові за генетичною інформативністю.

Плазма, наприклад, є носієм типових властивостей грунту. Тип організації плазми - відображення грунтогенезу. Значний вплив на плазму мають кислотно-лужні і окиснювально-відновні умови розчинів, властивості і заряд гідрофільних колоїдів, елювіальний й ілювіальні процеси, повторні зволоження i висушування (особливо, якщо вони супроводжуються незворотними процесами), повторні заморожування і відтавання i т. д. Відповідно до даних впливів грунт з своїм специфічним складом скелета і плазми буде розвивати характерні риси будови в залежності від специфічності навколишнього середовища.

Залежність між типом мікробудови, характеристикою профілю і умовами середовища чітко встановлена численними дослідженнями в усьому світі (Dumanski, 1964). Таким чином, окремі елементи мікроустрою або мікроознаки найбільш ефективно використовуються для інтерпретації елементарних грунтових процесів.

Як відомо, розподіл та форма скелетних зерен характеризують умови седиментації та процеси вивітрювання. Певний склад плазми (аморфний гумус, глина, сегрегаціï) характеризують різні горизонти, а біопори - тільки поверхневі.

Що стосується кутан, то відповідно до R. Bullock et al. (1970), аржиллани утворюються під час седиментації. Матричні i матричноглинисті кутани розглядаються як результат руйнування структури поверхневих горизонтів. Феррани, мангани, нодули - ознаки глеєвих явищ, а папули - це залишки старих грунтів (Русанова Г. В., 1998)

Отже, поява тих або інших мікроморф мінеральних новоутворень свідчить про зміни у гідротермічному режимі грунту. Встановлено, що різна форма і розмір новоутворень кальциту обумовлена різною концентрацією розчинів 3 яких вони випадають та різною швидкістю їх кристалізації. Формування відповідних типів мікроскладання відображає процес структуротворення, який залежить від життєдіяльності грунтової мезофауни. А наявність, кількісне співвідношення мікроформ органічної речовини, стадії трансформації органіки та форми гумусу характеризують процес гумусонакопичення (Брюером, 1964, Кубієна, 1967, Bullock, 1970, Русанова, 1998 та ін.).

Мета нашого дослідження - характеристика процесу грунтогенезу едафотопу дерноволітогенних грунтів на сіро-зелених глинах науково-дослідного стаціонару ДДАЕУ 3 сільськогосподарської рекультивації земель.
Методика досліджень. Матеріал відібраний на ділянці науково-дослідного стаціонару ДДАЕУ зі сільськогосподарської рекультивації земель, поблизу м. Покров Нікопольського району Дніпропетровської області. У дослідженнях застосовували загальноприйняті методи геоботанічного аналізу пробних площ та методологічні принципи екологічної мікроморфології грунтів, запропоновані Н. А. Біловою, А. П. Травлєєвим 3 відбором зразків по горизонтах дерноволітогенних грунтів на сіро-зелених глина [1].

Пробопідготовку проводили в лабораторії екологічного грунтознавства ДДАЕУ, виготовлення шліфів - в лабораторії мікроморфології грунтів НДІБ та кафедри геоботаніки, грунтознавства та екології ДНУ ім. О. Гончара.

Мікроморфологічна організація грунтів вивчена методами, розробленими Є. І. Парфеновою, Є. А. Яриловою [7], Е. І. Гагаріною [8] та Н. А. Біловою, А. П. Травлєєвим [10]. Прозорі шліфи виготовляли методом О.Ф. Мочалової, досліджували за допомогою поляризаційного мікроскопа «МБИ-15У» та стереоскопічного бінокуляра «МПСУ-1» (для мікрофотозйомки використовували цифрові фотонасадки). У розшифруванні шліфів застосовували «Методическое руководство по микроморфологии почв» за редакцією Г. В. Добровольського [8].

Результати досліджень. Науково-дослідний стаціонар із рекультивації земель Дніпровського державного аграрно-економічного університету поблизу м. Покров Нікопольського району Дніпропетровської області був спеціально створений у процесі гірничотехнічної рекультивації зовнішнього відвалу марганцевого кар'єру (АзовоПричорноморська південно степова провінція, $\left.47^{\circ} 39^{\prime} \mathrm{N}, 34^{\circ} 08^{\prime} \mathrm{E}\right)$.

Модель (конструкція) технозему - сіро-зелені глини (СЗГ), яка досліджувалась, була сформована техногенною сумішшю сіро-зелених мергелястих глин потужністю не менше 2 м без покриття родючим шаром чорнозему протягом 1968-1970 рр. Загальна площа моделі - 1 га. В сільськогосподарському освоєнні з 1971 року.

У представленій моделі технозему тривалий час (1992-2008 рр.) проводилися польові дослідження з багаторічними полікомпонентними агрофітоценозами: дослідними бобовими культурами були люцерна посівна (Medicago sativa L.), еспарцет піщаний (Onobrychis arenaria (Kit.) DC), буркун білий (Melilotus albus Medic.); злакові компоненти - стоколос безостий (Bromopsis inermis (Leyss.), житняк вузькоколосий (Agropyron desertorum Schult.) та райграс високий (Arrhena- 


\section{СІЛЬСЬКЕ ГОСПОДАРСТВО. ЕКОЛОГІЯ}

therum elatius (L.) J. Et Presl) [2].

Мікроморфологічна будова розрізу технозему (СЗГ):

- h1P1k1t 0-6 см: Неоднорідний за кольором горизонт, пухкий. Елементарне мікроскладення плазмово-піщане. Відсоткове співвідношення мінеральної частини $15 \%$. Скелет представлений в основному великими, світлими і непрозорими карбонатними утворенням (рис. 1 a), фракція середніх за розміром і дрібних зерен представлена слабо. Плазма гумусо-залізисто-глинисто-карбонатна. Гумусова частина плазми представлена невеликими гумонами та вуглеподібними частками. Залізисту частину плазми представляють гідроокиси заліза. Глиниста плазма 3 двозаломленням, неорієнтована. Карбонатна частина представлена дрібнозернистим кальцитом. Карбонати утворюють основу, в яку вмонтовуються інші частини плазми. Органічна речовина представлена дрібними вуглеподібними частками, в більшості випадків сконцентрованих у місцях розкладання коренів. Також представлені нечисленні свіжі зрізи рослин (рис. 1 б) та залишки із слідами розкладання, останні насичені або вкриті карбонатами. Горизонт має рихлий мікроустрій, шпаровий простір представлений в більшості міжагрегатними пустотами. Горизонт агрегований. Miкроагрегати у більшості випадків округлої форми, прості.

- h2P2k2t 6-20 см: Неоднорідно забарвлений го-
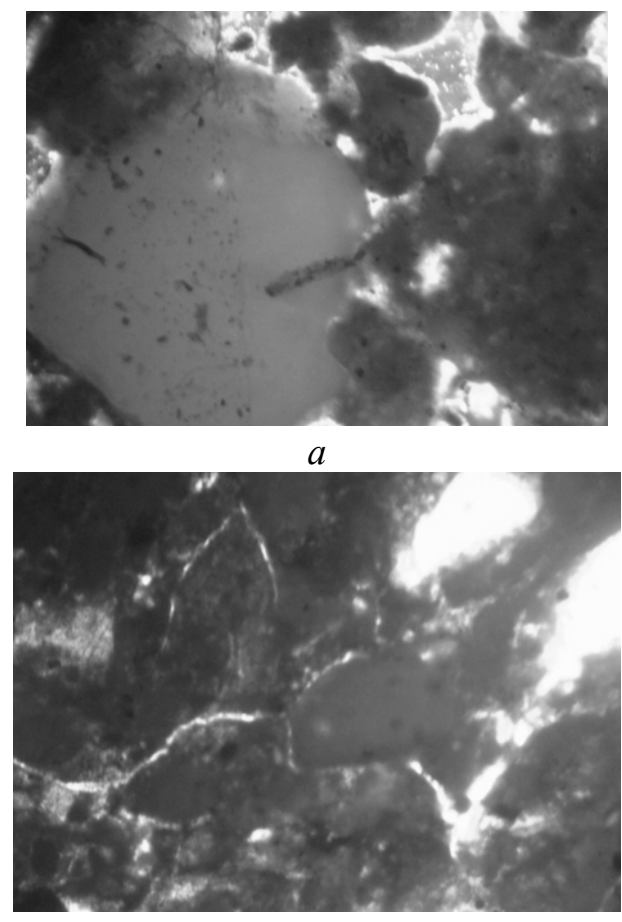

B ризонт, рихлий. Елементарне мікроскладення плазмово-піщане. Відсоткове співвідношення мінеральної частини $30 \%$. Скелет, так як і у попередньому горизонті, представлений в основному великими, світлими i непрозорими карбонатними утвореннями, фракція середніх за розміром і дрібних зерен представлена слабо. Форма карбонатних утворень близька до округлої. Кути згладжені, деякі утворення пронизують тріщини. Плазма - гумусозалізисто-глинисто-карбонатна. Гумусова частина плазми представлена невеликими гумонами та вуглеподібними частками, які нерівномірно розміщені в карбонатній основі (рис. 1 в). Залізисту частину плазми представляють гідроокиси заліза. Глиниста плазма $з$ двозаломленням, не орієнтована. Карбонатна частина представлена дрібнозернистим кальцитом який окантовує більшість утворень. Так як і в попередньому горизонті, карбонати утворюють основу, в яку вмонтовуються інші частини плазми. Органічна речовина представлена невеликою кількістю гумонів, свіжих зрізів коренів які знаходяться в основному в порах (рис. 1 г) та вугільних часток, в матеріалі основи розміщуються неоднорідно. Мікроустрій горизонту - рихлий. В більшості шпаровий простір представлений міжагрегатними пустотами, рідше трапляються тріщини. Агрегований горизонт, мікроагрегати коагуляційного походження, прості.

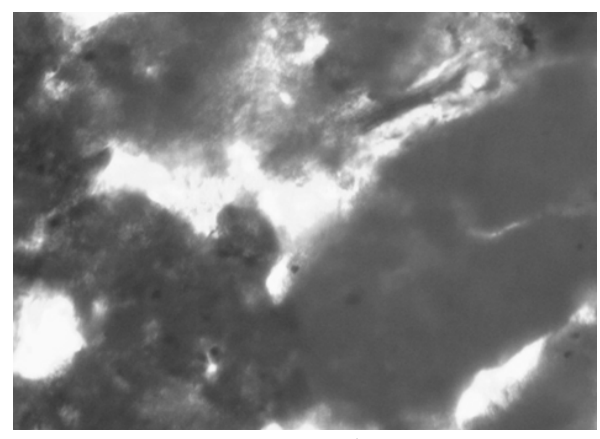

$\sigma$

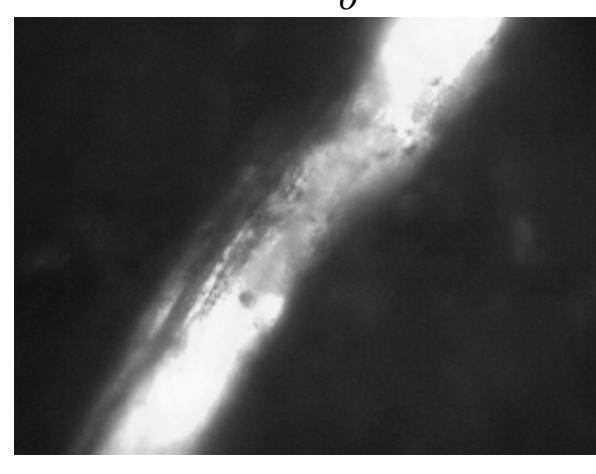

2

Рис. 1. Мікроморфологічні особливості горизонтів h1P1k1t 0-6 см ma h2P2k2t 6-20 cм $a$ - непрозорі карбонатні утворення; $\sigma$ - рослинні залишки на різних стадіях розкладення в - органічна речовина; 2 - зріз свіжого рослинного залишку; 


\section{СІЛЬСЬКЕ ГОСПОДАРСТВО. ЕКОЛОГІЯ}

- P3k3t 20-145 см: Більш щільний горизонт, частка шпарового простору порівняно 3 попередніми значно менша. В горизонті присутня значна кількість непрозорих карбонатних утворень. Елементарне мікроскладення - плазмово-піщане. Відсоткове співвідношення мінеральної частини $90 \%$. Скелет, представлений більшими за розмірами від попередніх горизонтів, світлими і непрозорими карбонатними утвореннями, фракція середніх за розміром і дрібних зерен представлена слабо. Форма і розмір карбонатних утворень відрізняється. В даному горизонті вони значно більші, мають витягнуту форму, більшість пронизують тріщини (рис. 2 а). Багато утворень розпалось внаслідок чого можна спостерігати скупчення цих утворень із «пазловою» структурою. Плазма глинисто-карбонатна. Глиниста частина плазми із двозаломленням, має шпарове, острівне і смугасте орієнтування. Карбонатна плазма представлена дрібнозернистим кальцитом. В площі шліфу існують різні мікрозони 3 дещо неоднаковим його вираженням i щільністю. Для всіх мікрозон шліфу характерне вкриття пор і структурних елементів дрібнозер-
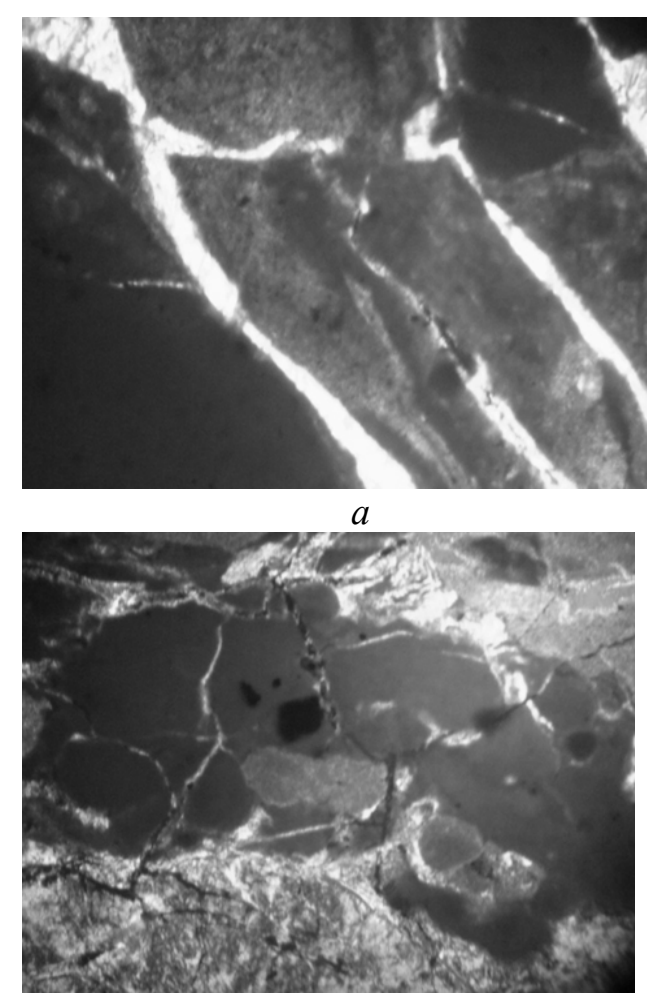

B нистим кальцитом. Мікроустрій шпаровий. Домінують шпарини-тріщини, незначна частка припадає на міжагрегатний простір та замкнені шпарини (рис. 2 б). Стінки шпарин вистелені дрібнозернистим кальцитом. Горизонт погано агрегований, мікроагрегати в основному прості, коагуляційного походження.

- P4t 145-210 см: Доволі рівномірно забарвлений горизонт, щільний. Скелет представлений незначною кількістю дрібних зерен та невеликих за розміром білих, непрозорих карбонатних утворень. Плазма глинисто-карбонатна. Глиниста частина представлена вкрапленнями різної форми у дрібнозернистий кальцит (рис. 2 в). Карбонатна частина займає найбільшу частку i представлена дрібнозернистим кальцитом. Мікроустрій горизонту - шпаровий, представлений тріщинами, які утворилися внаслідок усихання матеріалу основи (рис. 2 г). По стінкам шпарин, на відміну від попередніх горизонтів не виражено переміщення дрібнозернистого кальциту. В горизонті присутні блоки розтріскування, розмір і величина яких сильно варіює.
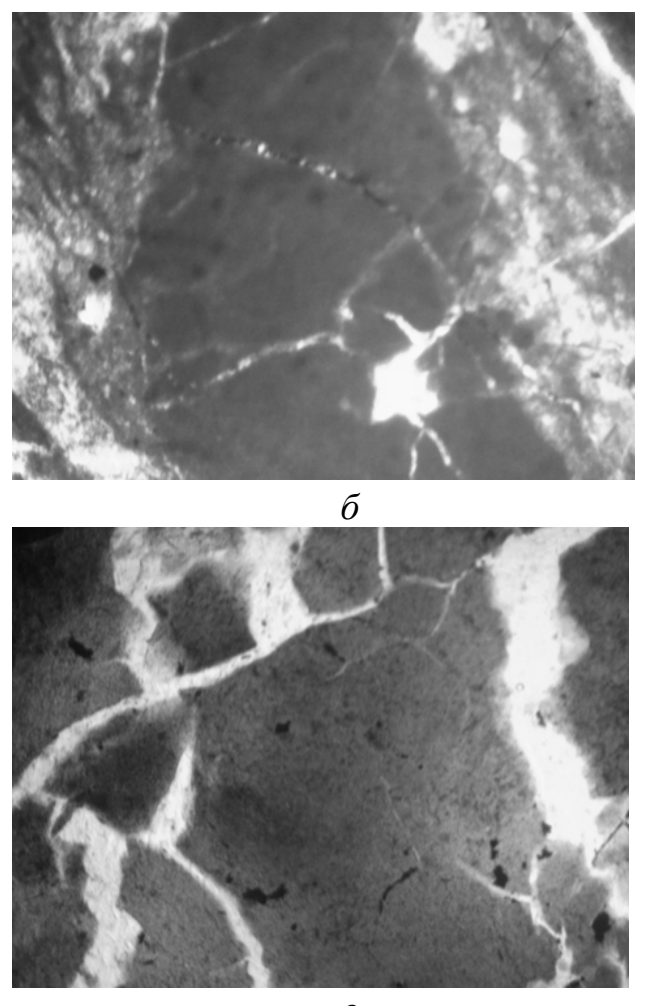

2

Рис. 2. Мікроморфологічні особливості горизонтів P3k3t 20-145 см та P4t 145-210 см

$$
\begin{gathered}
a-\text { карбонатні утворення прямокутної форми; } \\
\sigma-\text { шпаровий простір; } \\
\text { в- вкраплення глинистої плазми; } \\
2-\text { шпаровий простір. }
\end{gathered}
$$




\section{1. Основні морфологічні особливості та новоутворення дерново-літогенних трунтів на сіро-зелених глинах}

\begin{tabular}{|c|c|c|c|c|}
\hline Горизонт & $\begin{array}{c}\text { Тип кутан та } \\
\text { новоутворень }\end{array}$ & Мікроустрій & Плазма & Мікроструктура \\
\hline $\begin{array}{l}\mathrm{h}_{1} \mathrm{P}_{1} \mathrm{k}_{1} \mathrm{t} \\
0-6 \mathrm{~cm}\end{array}$ & $\begin{array}{c}\text { Дрібнозернистий } \\
\text { кальцит }\end{array}$ & Рихлий & $\begin{array}{c}\text { Гумусо- } \\
\text { залізисто- } \\
\text { глинисто- } \\
\text { карбонатна }\end{array}$ & Плазмово-піщана \\
\hline $\begin{array}{l}\mathrm{h}_{2} \mathrm{P}_{2} \mathrm{k}_{2} \mathrm{t} \\
6-20 \mathrm{~cm}\end{array}$ & $\begin{array}{c}\text { Дрібнозернистий } \\
\text { кальцит }\end{array}$ & Рихлий & $\begin{array}{c}\text { Гумусо- } \\
\text { залізисто- } \\
\text { глинисто- } \\
\text { карбонатна }\end{array}$ & Плазмово-піщана \\
\hline $\begin{array}{c}\mathrm{P}_{3} \mathrm{k}_{3} \mathrm{t} \\
20-145 \mathrm{~cm}\end{array}$ & $\begin{array}{c}\text { Дрібнозернистий } \\
\text { кальцит }\end{array}$ & Шпаровий & $\begin{array}{c}\text { Глинисто- } \\
\text { карбонатна }\end{array}$ & Плазмово-піщана \\
\hline $\begin{array}{c}\mathrm{P}_{4} \mathrm{t} \\
145-210 \mathrm{~cm}\end{array}$ & $\begin{array}{c}\text { Дрібнозернистий } \\
\text { кальцит }\end{array}$ & Шпаровий & $\begin{array}{l}\text { Глинисто- } \\
\text { карбонатна }\end{array}$ & Плазмово-піщана \\
\hline
\end{tabular}

Мікроструктура плазмово-піщана, однорідна по всьому профілі. Скелет в верхніх горизонтах (h1P1k1t 0-6 см та h2P2k2t 6-20 cм) відносно однорідний, представлений в основному великими, світлими і непрозорими карбонатними утвореннями, які збільшуються з глибиною.

На відміну від попередніх горизонтів скелет горизонту P4t 145-210 см представлений незначною кількістю дрібних зерен та невеликих за розміром білих, непрозорих карбонатних утворень. Плазма в двох верхніх горизонтах гумусозалізисто-глинисто-карбонатна, в двох нижніх глинисто-карбонатна. Без орієнтування. Мікроскладення в верхніх горизонтах рихле, в нижніх - шпарове. Шпаровий простір поступово змінюється від агрегатних пустот в верхньому горизонті (h2P2k2t 6-20 см) до шпарин тріщин у нижньому горизонті (Р4t 145-210 см).

Агрегованість горизонтів також змінюється 3 глибиною. Горизонти h1P1k1t 0-6 cм та h2P2k2t 6-20 см добре агреговані, на відміну від горизонтів P3k3t 20-145 см та P4t 145-210 см. В основному мікроагрегати прості по всьому профілю, коагуляційного походження. Горизонт P4t 145210 см складений блоками розтріскування.
Найбільш характерні новоутворення для цього профілю $є$ дрібнозернистий кальцит, який насичує матеріал основи, та його вицвіти в порах.

Висновок. Для кожного горизонту характерне домінування карбонатів. У верхніх горизонтах, внаслідок дії кліматичних та біологічних чинників, карбонатні утворення значно менші за розмірами, кількість великих - незначна.

3 глибиною зменшується ефект вивітрювання, як наслідок - карбонатні частки значно більші за розмірами.

Органічна речовина представлена в основному тільки у верхніх горизонтах до глибини $20 \mathrm{~cm}$. В основному вона представлена чорним гумусом, гумонами та свіжими рослинними залишками.

Відсутність проміжних стадій розкладання свіжих рослинних залишків свідчить про високу швидкість розкладання органічної речовини.

Подальші дослідження сприятимуть вивченню механізмів відтворення родючості рекультивованих грунтів, а отримані результати будуть використані для розробки грунтово-екологічного моніторингу та системи заходів з біологічної рекультивації відвалів гірських порід. 


\section{БІБЛІОГРАФІЯ}

1. Андрусевич К. В. Екологічна різноманітність рослинного покриву техноземів ділянки рекультивації Нікопольського марганцево-рудного басейну / К. В. Андрусевич, Ю. О. Штірц // Промислова ботаніка: збірка наукових праць. - Донецьк: Донецький ботанічний сад НАН України, 2014. - Вип. 14. - С. 115-127.

2. Гаврюшенко О.О. Агроекологічне обгрунтування динаміки едафічних характеристик рекультивованих земель при їх сільськогосподарському освоєнні в нікопольському марганцеворудному басейні: Автореф. дисер. на здобуття наукового ступеня канд.. с.-г. наук. - Дніпро, 2017. $-28 \mathrm{c}$.

3. Демидов А. А. Пространственная агроэкология: монография / Демидов А. А., Кобец А. С., Грицан Ю. І., Жуков А. В. - Днепропетровск : Изд-во «Свидлер А.А.», 2012. - 390 с.

4. Качевич В. В. Мікроморфологічна характеристика дерново-літогенних грунтів на лесах / В. В. Кацевич // Матеріали III Всеукраїнської науково-практ. конф. «Молодь: наука та інновації - 2015». - Дніпропетровськ, 2015. - Т. 10. C. 27-28.

\section{ANNOTATION}

Katsevych V. V., Hrytsan Yu. I. Edaphic characteristics of soddy-lithogenic soil on greygreen clays on the basis of environmental micromorphology.

In general, in Ukraine the rate of land alienation with the purpose of mining operations is far ahead of the rate of reclaimed areas recovery. As a result, the problem of disturbed lands reclamation and their returning to economic use becomes a high priority state problem.

The objective of our study was characterizating the pegogenesis of soddy-lithogenic soil onto greygreen clay in the condition of land reclamation of the Research-Experimental Agrarian Station of Dnipro State Agrarian-Economic University (DSAEU).

According to the results of micromorphological study of soddy-lithogenic soils onto grey-green clay conducted at DSAEU Research-Experimental Agricultural Station near Pokrov city, Nikopol district of Dnipropetrovsk region, agroecological substantiation of pedogenesis was presented.

The peculiarities of the micromorphological structure of technozem on the experimental plot of
5. Кобец А. С. Концептуальные основы устойчивого развития нарушенных природных экосистем / [Кобец А. С., Волох П. В., Узбек И. Х. и др.]; под ред. П. В. Волоха, И. Х. Узбека. - Днепропетровск : Изд-во «Свидлер А.Л.», 2012. $125 \mathrm{c}$.

6. Мочалова Э. Ф. Изготовление шлифов из почв с ненарушенным строением / Э. Ф. Мочалова // Почвоведение. - 1956. - № 10. - С. 98 100.

7. Парфенова Е. И. Руководство к микроморфологическим исследованиям в почвоведении / Е. И. Парфенова, Е. А. Ярилова. - М. : Наука, 1977. - $198 \mathrm{c}$.

8. Природні ліси та степові грунти / Білова Н. А., Травлеев А. П. - Дніпропетровськ : видво ДНУ, 1999. - 348 с.

9. Kubiena W. L. The soils of Europe / W. L. Kubiena. - London : Thomas Murby, 1953. - 298 p.

10. Gagarina E. I. [Micromorphological method for studying soil]. - St. Petersburg : St. Petersburg University Press, 2004. - 201 p.

agricultural reclamation were studied. It was established that the dominance of carbonates is common in each soil horizon. Due to effect of climatic and biological factors, calcareous neoformations in the topsoil are much smaller in size in comparison with subsoil, and the number of large ones is negligible. With the depth, the effect of weathering decreases, leading to much larger size of calcareous neoformations. Micromorphological studies show that fine-grained calcite was the most common type of neoformations in the soil profile, which saturates the material with bases, and its mottles in pores. It was determined that organic substance was contained mainly in the upper soil horizons $20 \mathrm{~cm}$ deep. It is mainly represented by black humus, gumones and fresh plant residues. The absence of the intermediate stages of fresh plant residues decomposition provides the evidence of a high rate of organic matter decomposition.

Key words: edaphotop, technozem, soddylithogenic soil onto grey-green clay, soils micromorphology, pedogenesis, structure formation, mineral neoformations. 